\title{
FAKTOR-FAKTOR YANG MEMPENGARUHI PENDAPATAN PEDAGANG BERAS DALAM MENGHADAPI FLUKTUASI HARGA DI KOTA MANADO
}

\author{
Ernia Sondakh \\ Rine Kaunang \\ Paulus Adrian Pangemanan
}

\begin{abstract}
The purpose of this study is to analyse the factors that influence rice traders income to price increases in Pasar Bersehati Calaca and Pasar Pinasungkulan Karombasan Manado. To answer this purpose, analysis of multiple regressions is used. The study is conducted from Desember 2015 to January 2016 by using secondary data of Badan Pusat Statistik Sulawesi Utara, namely percentage pricechange from January 2015 until Desember 2015, and primary data taken from rice traders by using questionnaire. Result show that capital, price, stock, and output simultaneously have significant influence to income of rice traders. Partially, capital and output have positive influence to income of rice traders, whereasprice and stock have negative influence to income of rice traders.
\end{abstract}

Keywords : determinant factors, rice traders income, price fluctuation, Bersehati dan Pinangkulan traditional markets, Manado City

ABSTRAK

Penelitian ini bertujuan untuk menganalisis Faktor-faktor yang mempengaruhi Pendapatan Pedagang Beras di Pasar Bersehati Calaca dan Pasar Pinasungkulan Karombasan Kota Manado dalam menghadapi kenaikan harga. Dalam menjawab tujuan penelitian ini maka digunakan analisis regresi linear berganda. Penelitian dilaksanakan pada Bulan Desember 2015 hingga Januari 2016, data yang digunakan adalah data sekunder dari Badan Pusat Statistik Sulawesi Utara berupa data persentase perubahan harga dari Bulan Januari 2015 hingga Bulan Desember 2015, dan data primer dari pedagang-pedagang beras, lewat penyebaran kuesioner dan wawancara. Hasil penelitian menunjukkan bahwa secara simultan modal, harga, stok, dan output berpengaruh secara signifikan terhadap pendapatan. Secara parsial modal dan output berpengaruh positif terhadap pendapatan pedagang beras, sedangkan harga dan stok berpengaruh negatif terhadap pendapatan pedagang beras.

Kata kunci: faktor-faktor yang mempengaruhi, pendapatan pedagang beras, fluktuasi harga, pasar tradisional Bersehati dan Pinangsungkulan, Kota Manado

\section{PENDAHULUAN}

\section{Latar Belakang}

Harga merupakan salah satu bagian yang penting dalam pemasaran, harga juga merupakan nilai tukar dari produk maupun jasa, dan harga adalah salah satu penentu keberhasilan. Menurut Kotler (2005) dalam Adriyansya (2014) harga adalah salah satu bauran pemasaran yang menghasilkan pendapatan, unsur lainya menghasilkan biaya. Penetapan harga yang terlalu tinggi akan menyebabkan penjualan akan menurun, namun harga yang terlalu rendah akan mengurangi keuntungan yang dapat diperoleh. Kenaikan harga adalah masalah rumit yang sering kali terjadi di dalam dunia ekonomi. Kurangnya kebutuhan pokok di Indonesia sehingga menjadikan harga barang-barang pokok menjadi semakin tinggi. Masalah kenaikan harga sembako selalu terjadi di Kota Manado yang disebabkan cuaca yang tidak menentu, atau menjelang hari raya. Kenaikan yang terjadi pada beberapa kebutuhan pokok seperti daging ayam, beras, gula, sayur-sayur dan kebutuhan pokok lain (Disperindag, 2015). Komoditas yang mengalami kenaikan harga antara lain cabai rawit, tomat sayur, angkutan dalam Kota, bensin, semen, tarif listrik, cabai merah, bawang merah, beras, emas perhiasan, mie, paket liburan, angkutan antar Kota, tarif parkir, nasi dengan lauk, seng, telur ayam ras, 
bahan pelumas/oli, apel, pasta gigi, ekor kuning, angkutan udara, bawang putih, kendaraan carter/rental, soto, mujair, kembang kol, tarif sewa motor, sate, sawi hijau, roti tawar, pisang, ayam hidup, kangkung, gula pasir, daun bawang, coklat batang, blus, kakap putih, pepaya, buncis dan lain-lain (Anonimous, 2015).

Penyumbang inflasi salah satunya beras karena beras pangan pokok yang selalu di konsumsi masyarakat, akibat adanya kenaikan yang terjadi hampir setiap Bulan mengalami kenaikan dan selalu berlangsung setiap tahun. Beras adalah salah satu komoditi pangan utama yang dikonsumsi oleh hampir 90\% penduduk di Indonesia dan mengandung nilai gizi lebih baik dibandingkan dengan makanan pokok lainnya (Mulyo, 2011), dan beras memiliki peran yang sangat strategis dalam memantapkan ketahanan pangan. Ketergantungan akan beras masih sangat tinggi dan beras masih menjadi primadona bagi masyarakat, khususnya di Kota Manado beras menjadi salah satu komoditi yang masuk dalam perhitungan inflasi, dimana sumbangan inflasi untuk komoditi beras sangat besar, penyebabnya karena harga beras terus meningkat dan mahalnya harga beras dikarenakan cuaca yang tidak menentu sehingga mengakibatkan menurunkan produksi padi.

Gambar 1 menyajikan data yang diambil dari Badan Pusat Statistik yang menjelaskan presentase perubahan harga khusus untuk komoditi beras dari Bulan Januari sampai Bulan Oktober tahun 2015. Gambar 1 menjelaskan hampir pada setiap Bulan harga beras selalu berfluktuasi, dari Bulan Januari sampai Bulan Maret terjadi kenaikan harga beras dari 1,0589\% sampai $11,3324 \%$ dan pada Bulan April harga beras mengalami penurunan yang drastis hingga negatif, dari 11,332\% turun menjadi $-11,0985 \%$, pada Bulan selanjutnya dari Bulan Mei sampai September mengalami kenaikan harga beras secara terus menerus dari $-4,3900 \%$ sampai $5,4278 \%$, dan pada Bulan Oktober harga beras mengalami penurunan harga $-2,6400 \%$. Fluktuasi harga yang terjadi menimbulkan kebingungan dan meresahkan masyarakat.
Masalah kenaikan harga selalu membawa pengaruh bagi setiap elemen masyarakat yang terlibat didalamnya tidak terkecuali bagi produsen. Masalah kenaikan harga membuat masyarakat resah dari sisi konsumen maupun produsen karena harga kebutuhan-kebutuhan pokok khususnya beras meningkat karena adanya kelangkaan yang terjadi di pasar-pasar dan juga permintaan akan barang meningkat khususnya kebutuhan pokok, dan pola konsumsi masyarakat yang berubah dimana semula pola konsumsi masyarakat hanya untuk sesaat itu saja tapi sekarang berubah dengan upaya masyarakat untuk memenuhi kebutuhan jangka waktu yang lebih lama. Kebutuhan masyarakat yang meningkat yang tidak diikuti dengan ketersediaan kebutuhan pokok hal inilah yang membuat kekwatiran akan pedagang-pedagang beras, karena pedagang memiliki fungsi untuk menciptakan ketersediaan beras sesuai dengan keinginan konsumen sehingga pedagang beras berusaha untuk menyediakan kebutuhan pokok masyarakat.

Kenaikan harga bersifat tidak teratur, yang mengakibatkan para produsen mengalami kesulitan dalam menghitung harga pokok produksi barang yang diproduksi, maka mengakibatkan proses perhitungan harga pokok produksi tidak akurat bisa terjadi terlalu rendah atau mungkin terlalu tinggi. Akibat dari ketidaktepatan atau ketidakakuratan perhitungan harga pokok produksi maka mempersulit para produsen dalam menentukan harga jual barang yang telah dihasilkannya.

Kenaikan harga menimbulkan pengaruh terhadap pedagang dalam menangani modal, stok, harga, output, hingga perubahan pendapatan yang di alami pedagang. Sebagian pedagang berpendapat kenaikan harga memberikan pendapatan yang bertambah dan sebagian pedagang berpen-dapat kenaikan harga memberikan kerugian dengan mengakibatkan berkurangnya pendapatan dikarenakan permintaan konsu-men. Menghadapi kenaikan harga pedagang membuat stategi dan keputusan yang berbedabeda yang bertujuan untuk mempertahankan bisnis yang telah dijalani.

Kenaikan harga yang selalu terjadi akan mempengaruhi pendapatan pedagang 
beras. Harga mahal dapat meningkatkan laba jangka pendek, tetapi di sisi lain akan sulit di jangkau konsumen (Tjiptono dan Chandra, 2012). Mengantisipasi masalah kenaikan harga, pemerintah bahkan pedagang beras khususnya pedagang pasar Bersehati Calaca dan pasar Pinasungkulan Karombasan Kota Manado harus memperhatikan faktor internal dan faktor eksternal yang dapat berpengaruh dalam setiap aktivitas ekonomi dari pedagang beras.

Penelitian dari Artaman (2015) dengan judul Analisis Faktor-Faktor Yang Mempengaruhi Pendapatan Pedagang Pasar Seni Sukawati Di Kabupaten Gianyar, dari hasil pengamatan dan wawancara yang dilakukan, faktor internal seperti modal usaha yang digunakan sebagian besar merupakan modal sendiri, lama usaha yang bervariasi, dan jam kerja yang pendek cenderung berpengaruh terhadap pendapatan pedagang yang diperoleh, Sedangkan faktor eksternal yaitu perbedaan lokasi usaha yang strategis dan tidak strategis serta fasilitas parkir yang tidak luas dan tidak nyaman merupakan faktor penting lainnya, wisatawan menjadi enggan untuk berkunjung ke Pasar Seni Sukawati. Penelitian dari Ma'arif (2013) dengan Judul Analisis Faktor-faktor yang mempengaruhi Pendapatan Pedagang Pasar Bandarjo Ungaran Kabupaten Semarang faktor-faktor yang mempengaruhi pendapatan pedagang yaitu modal merupakan salah satu faktor penting dalam suatu produksi, lokasi yang tepat, kondisi tempat berdagang.

Hubungan antara penelitian terdahulu dan penelitian ini, membahas tentang faktorfaktor yang mempengaruhi pendapatan pedagang, salah satu kesamaan faktor yang mempengaruhi yaitu modal, selain modal dalam penelitian ini melihat faktor-faktor lain yang mempengaruhi pendapatan dari pedagang beras yaitu harga beras, stok beras, output pedagang beras atau jumlah beras yang terjual.

Kenaikan harga ini juga dirasakan pedagang di Kota Manado khususnya di pasar Bersehati Calaca dan pasar Pinasungkulan Karombasan, dimana permintaan tidak diimbangi dengan penawaran akan beras, pedagang sering juga kehabisan stok beras, dan harga beras selalu berfluktuasi dari menjelang hari raya maupun hari-hari biasa, hal inilah yang membuat pedagang kawatir.

Dari latar belakang atau masalah kenaikan harga yang sering dihadapi oleh setiap Negara baik Negara berkembang maupun Negara maju, bahkan di Kota Manado pun tidak lepas dengan masalah kenaikan harga yang terjadi secara terus menerus yang diakibatkan salah satunya oleh komoditi pangan pokok utama yaitu beras sehingga penulis tertarik untuk melihat Faktor-faktor yang mempengaruhi Pendapatan Pedagang Beras di Kota Manado dalam menghadapi Fluktuasi Harga, khusus pedagang beras di Pasar Bersehati Calaca dan Pasar Pinasungkulan Karombasan Kota Manado.

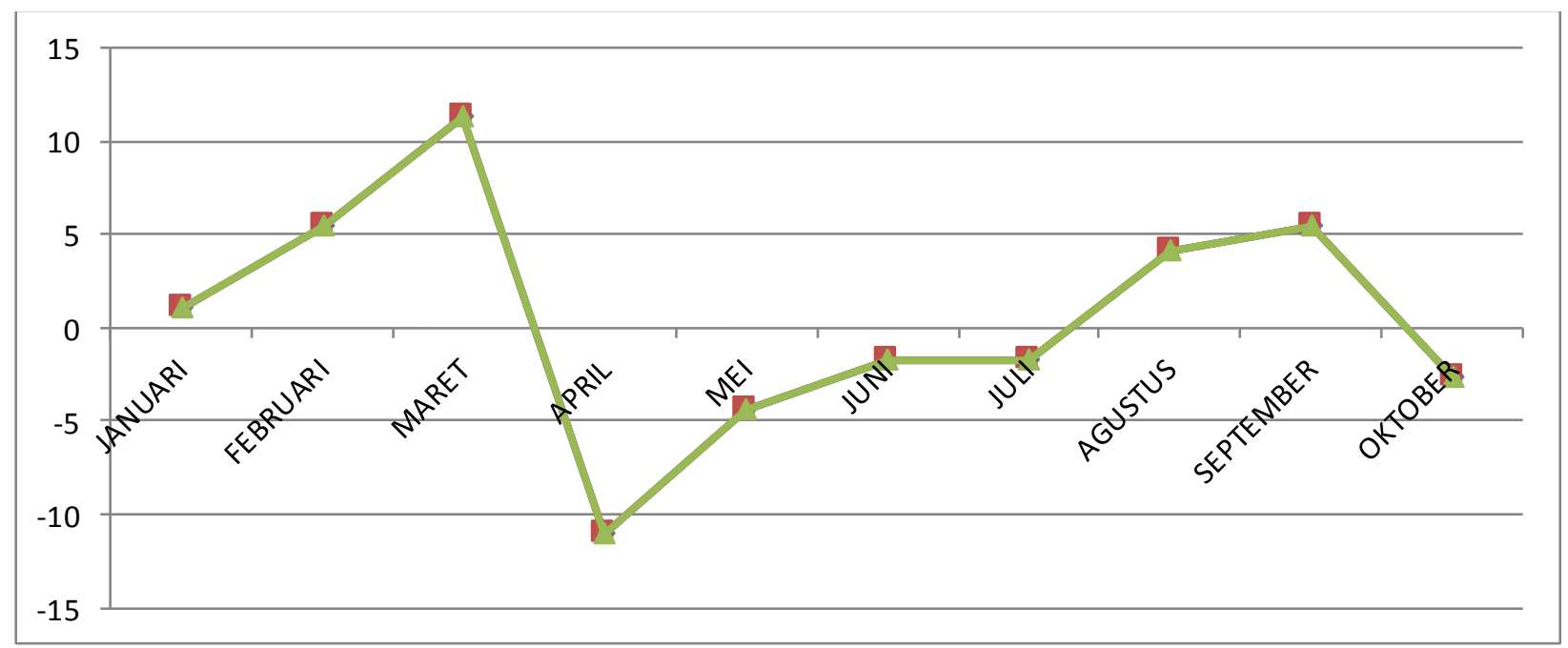

Gambar 1. Persentase Perubahan Harga Komoditi Beras di Kota Manado Provinsi Sulawesi Utara Tahun 2015 


\section{Harga}

Harga adalah jumlah uang yang ditetapkan oleh produk untuk dibayar oleh konsumen atau pelanggan guna menutupi biaya produksi, distribusi dan penjualan pokok termasuk pengembalian yang menandai atas usaha dan resikonya (Kotler, 2000 dalam Adi, 2012). Harga merupakan cerminan dari interaksi antara penawaran dan permintaan yang bersumber dari sektor rumah tangga sebagai sektor konsumsi dan sektor industri sebagai sektor produksi (Hanafie, 2010). Harga adalah sejumlah nilai yang ditukarkan konsumen dengan manfaat dari memiliki atau menggunakan produk barang atau jasa yang nilainya ditetapkan oleh pembeli dan penjual melalui tawar-menawar atau ditetapkan oleh penjual untuk suatu harga yang sama terhadap seorang pembeli (Husein, 2002 dalam Adi, 2012).

Perusahaan menurunkan harganya, maka para pesaingnya harus menurunkan pula harga mereka. Kondisi seperti ini yang mendasari terbentuknya tujuan stabilisasi harga dalam industri-industri tertentu yang produknya terstandardisasi. Tujuan stabilisasi ini dilakukan dengan jalan menetapkan harga untuk hubungan yang stabil antara harga suatu perusahaan dan harga pemimpin industri. (Tjptono, 2008 dalam Adi, 2012).

\section{Definisi Pedagang}

Pedagang adalah salah satu yang melaksanakan kegiatan ekonomi, dan tugas pedagang adalah melakukan perdagangan, memperjualbelikan barang yang bertujuan untuk memperoleh keuntungan. Beberapa jenis pedagang yaitu :

a) Eksportir adalah pedagang yang melakukan kegiatan dengan menjual barang keluar negeri

b) Importir adalah pedagang yang melakukan kegiatan membeli atau mendatangkan barang dari luar negeri, yang bertujuan untuk memenuhi kebutuhan dalam negeri.

c) Agen tunggal atau pedagang besar (distributor) adalah pedagang yang melakukan penjualan kepada pedagang menengah atau grosir, dimana distributor ini melakukan pembelian dan mendapatkan barang secara langsung dari produsen.

d) Pedagang menengah atau grosir adalah pedagang yang membeli barang secara langsung pada agen tunggal atau distributor, atau perusahaan yang bersangkutan, kemudian melakukan penjualan pedagang kecil atau pedagang pengecer seperti toko, atau warung, pasar swalayan.

e) Pedagang eceran atau retailer adalah pedagang yang membeli barang dari pedagang menengah atau grosir dan kemudian menjual kepada konsumen. Pedagang eceran atau retailer adalah pedagang yang berhungan langsung dengan konsumen akhir.

\section{Definisi Ekonomi}

Ekonomi adalah sebuah ilmu yang mempelajari bagaimana manusia mencukupi kebutuhannya hidupnya seperti produksi, distribusi, dan konsumsi terhadap barang dan jasa. Kata ekonomi berasal dari bahasa Yunani, yaitu (oikos) yang berarti "keluarga, rumah tangga" dan (nomos) yang berarti "peraturan, aturan, hukum". Jadi pengertian ekonomi pada dasarnya adalah ilmu yang mengatur rumah tangga atau aktivitas manusia. Ilmu ekonomi adalah suatu studi mengenai bagaimana orangorang dan masyarakat menggunakan pilihan, dengan atau tidak menggunakan uang dengan meng-gunakan sumber daya yang terbatas tetapi dapat digunakan dalam berbagai cara untuk menghasilkan berbagai jenis barang dan jasa dan mendistribusikannya untuk keperluan sekarang dan di masa datang (Nuraini, 2002). Ekonomi merupakan kegiatan yang dilakukan oleh manusia yang bertujuan untuk memenuhi setiap kebutuhan masing-masing dari individu.

\section{Deskripsi Beras}

Beras adalah hasil olahan dari produk pertanian yang disebut padi (oryza sativa L.). Beras merupakan komoditas pangan yang di jadikan makanan pokok bagi bangsa Asia, khusus Indonesia, Thailand, Malaysia, Vietnam, jepang, dan Nyanmar (Ambarinanti, 2007 dalam Hessie, 2009). KBBI men-definisikan kata beras padi 
yang telah terkelupas kulitnya dan biji-bijian; butir-butiran (seperti jagung, kopi). Padi adalah jenis bahan pangan yang merupakan tanaman dari wilayah Asia.

\section{Kerangka Berpikir Teoritis}

Berdasarkan konsep-konsep dasar dan penelitian terdahulu yang dijelaskan di atas, maka disusun sebuah kerangka pemikiran teoritis seperti yang seperti yang ada di Gambar 2 sebagai berikut:

Gambar 2. Kerangka Pemikiran Teoritis

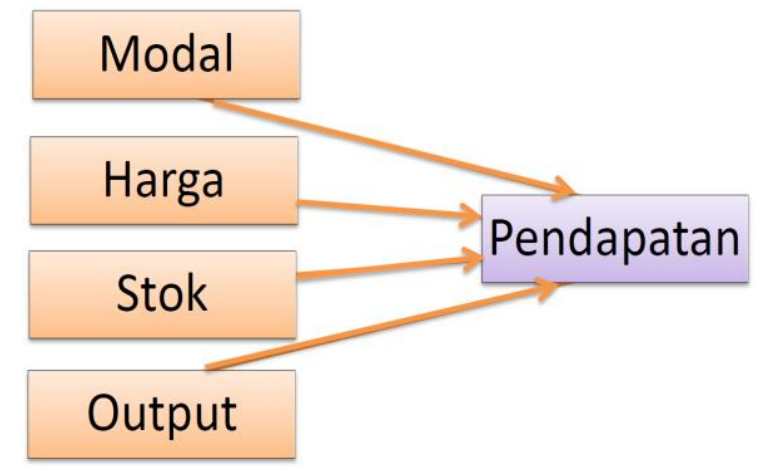

\section{Rumusan Masalah}

Faktor-faktor apa yang berpengaruh pada pendapatan pedagang beras dalam menghadapi fluktuasi harga di Kota Manado?

\section{Tujuan Penelitian}

Menganalisis faktor-faktor yang mempengaruhi pendapatan pedagang beras dalam menghadapi fluktuasi harga di Kota Manado?

\section{Manfaat Penelitian}

Manfaat dari penulisan ini adalah untuk memberikan informasi dan masukan tentang faktor-faktor yang mempengaruhi pendapatan pedagang beras dalam menghadapi fluktuasi harga di Kota Manado?

\section{Hipotesa Penelitian}

$\mathrm{H}_{0 \text { : }}$ Modal, harga, stok, output, tidak mempengaruhi pendapatan pedagang beras di pasar Kota Manado dalam menghadapi kenaikan harga $\mathrm{H}_{1}$ : Modal, harga, stok, output, mempengaruhi pendapatan pedagang beras di Pasar Kota Manado dalam menghadapi kenaikan harga.

\section{METODOLOGI PENELITIAN}

\section{Tempat dan Waktu Penelitian}

Penelitian dilaksanakan pada Pasar Bersehati Calaca dan Pasar Pinasungkulan Karombasan Manado serta Badan Pusat Statistik Provinsi Sulawesi Utara, selama dua Bulan di mulai pada Bulan Desember 2015 hingga Bulan Januari 2016.

\section{Metode Pengumpulan Data}

Metode pengumpulan data dalam penelitian ini dilakukan untuk memperoleh data primer yaitu data dari pedagang pengumpul dan pedagang pengecer dan data sekunder yaitu data dari Badan Pusat Statistik. Populasi dalam penelitian ini adalah semua pedagang beras di Pasar Bersehati Calaca sebanyak 40 pedagang beras dan semua pedagang beras di Pasar Karombasan sebanyak 45 pedagang beras, dan sampel untuk pasar Bersehati Calaca sebanyak 12 pedagang beras dan sampel di pasar Karombasan sebanyak 19 pedagang beras, pengambilan sampel dengan cara purposive sampling. Penelitian ini menggunakan teknik pengumpulan data dengan wawancara dan menyebarkan kuisioner serta data dari Badan Pusat Statistik Provinsi Sulawesi Utara. Data yang diambil berupa data (time series) yaitu data yang disusun berdasarkan waktu dari Bulan januari sampai Desember 2015.

\section{Konsep Variabel}

Variabel yang digunakan dalam penelitian ini adalah :

\section{Modal}

Modal merupakan variabel yang di ukur dimana modal digunakan untuk membeli kembali barang, yang di peroleh dari hasil pendapatan sebelum. Melihat keadaan pedagang dalam menghadapi kenaikan harga dengan Modal bertambah. Modal tetap, atau modal berkurang, serta mengetahui adanya pengaruh modal terhadap pendapatan pedagang beras (Rp/Bulan).

\section{Harga}

Harga merupakan variabel yang di ukur untuk menjadi sumber keuntungan pedagang, 
mengetahui harga beli dari pedagang pengecer dan pedagang pengumpul dan harga jual dari pedagang konsumen akhir. Melihat apakah harga beras perBulanya selalu naik atau tidak selalu naik, serta untuk mengetahui adanya pengaruh harga beli beras terhadap pendapatan pedagang $(\mathrm{Rp} / \mathrm{Krg})$.

\section{Stok}

Stok merupakan variabel yang diukur, untuk persediaan meliputi barang-barang (beras) pedagang dengan tujuan untuk memenuhi permintaan konsumen. Melihat keadaan pedagang menanggapi kenaikan harga, Pedagang dengan Stok bertambah, stok tetap, dan stok yang berkurang, serta untuk mengetahui adanya pengaruh stok terhadap pendapatan pedagang (Kg atau Karung).

\section{Output}

Output merupakan variabel yang diukur dimana output merupakan hasil yang keluarkan dari suatu proses, atau jumlah beras yang di jual oleh pedagang. Melihat keadaan pedagang menghadapi kenaikan harga, pedagang dengan output yang bertambah, output yang tetap, dan output yang berkurang, serta untuk mengetahui adanya pengaruh output terhadap pendapatan pedagang ( $\mathrm{Kg}$ atau Karung).

\section{Dummy}

Variabel yang di ukur, untuk mengetahui apakah kenaikan harga mempengaruhi pendapatan. Variabel yang dibuat skor $0=$ tidak selalu naik dan $1=$ selalu naik.

\section{Metode Analisis Data}

Analisis yang digunakan dalam penelitian ini adalah analisis deskriptif, yang digunakan untuk menganalisis data dengan cara mendeskripsikan atau menggambarkan data yang telah terkumpul, dengan menggunakan tabel dan gambar, dan analisis regresi menggunakan program SPSS.

Metode analisis yang digunakan penelitian untuk mencari pengaruh variabel bebas dan variabel terikat. Penelitian ini untuk melihat pengaruh antara modal pedagang beras, harga beras, stok pedagang beras, output dari pedagang beras, terhadap pendapatan pedagang beras di pasar bersehati calaca dan pasar pinasungkulan Kota Manado. Metode yang digunakan metode analisis regresi berganda.

$$
\begin{aligned}
& Y=a+\beta_{1} X_{1}+\beta_{2} X_{2}+\beta_{3} X_{3}+\beta_{4} X_{4}+\beta_{5} X_{5}+\mu \\
& \text { Dimana } \mathrm{Y}=\text { Pendapatan Pedagang }(\mathrm{Rp}) \\
& \mathrm{X}_{1} \quad=\text { Modal Pedagang }(\mathrm{Rp}) \\
& \mathrm{X}_{2}=\text { Harga Beras (Rp) } \\
& \mathrm{X}_{3}=\text { Stok beras }(\mathrm{Kg} \text { atau } \mathrm{Krg}) \\
& \mathrm{X}_{4}=\text { Output Pedagang }(\mathrm{Kg} \text { atau }
\end{aligned}
$$

\section{HASIL DAN PEMBAHASAN}

\section{Gambaran Umum Lokasi Penelitian}

Pasar besar yang ada di Manado yaitu pasar Bersehati terletak di Jl. Nusantara kelurahan Calaca kecamatan Wenang dan pasar Pinasungkulan Karombasan terletak di Jl. Pasar Karombasan kecamatan Wanea Kota Manado Provinsi Sulawesi Utara. Pasar Bersehati dibangun pada tahun 1972 sedangkan pasar Pinasungkulan Karombasan di bangun pada tahun 1976 dengan jumlah pedagang keseluruhan pada pasar Pinasungkulan Karombasan sebanyak 1.030 orang pedagang dengan luas lahan yang dimiliki $20.000 \mathrm{M}^{2}$ sedangkan jumlah pedagang di pasar Bersehati sebanyak 1.208 orang pedagang dengan luas lahan yang dimiliki $50.000 \mathrm{M}^{2}$, untuk jumlah pedagang khusus pedagang beras, pasar Bersehati Calaca sebanyak 40 pedagang dan pasar Pinasungkulan Karombasan sebanyak 45 pedagang beras. Penelitian ini mengarah pada pedagang pengumpul bahkan pedagang eceran. (PD. Pasar Kota Manado, 2016).

\section{Perubahan Harga Kebutuhan Pokok Beras} Gambar 3 menunjukkan perkembangan harga jual dari pedagang ke konsumen yang terjadi di Provinsi Sulawesi Utara dari 
Bulan Januari sampai Bulan Desember tahun 2015, harga ini juga berlaku pada semua pedagang di Kota Manado. Perubahan harga yang di ambil dari pusat informasi harga bahan pokok strategis di Profinsi Sulawesi Utara (PIHBS), yang di pantau oleh tim pengendali inflasi daerah (TPID).

Gambar 3 menunjukkan perubahan harga jual pedagang beras pada Bulan Januari, perubahan harga terjadi secara tidak menentu. Minggu ke dua pada Bulan januari terjadi kenaikan harga jual beras pada tanggal 9 harga beras $\mathrm{Rp} .12 .102 / \mathrm{Kg}$ berubah naik menjadi $\mathrm{Rp}$. $16.190 / \mathrm{Kg}$ pada tanggal 10, dan harga beras kembali menurun pada tanggal 11 kembali ke harga Rp. 12.100/Kg, dan pada tanggal $23 \mathrm{ke}$ tanggal 24 harga beras kembali naik menjadi Rp. 16.180 terus berlanjut sampai akhir Bulan Januari.

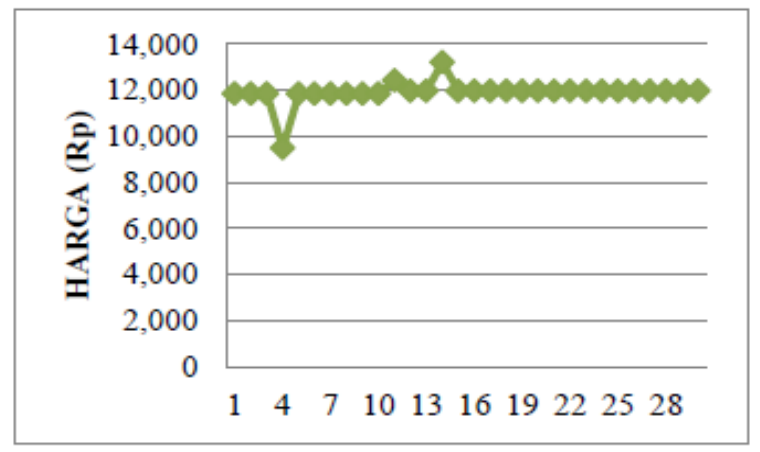

Gambar 3. Perubahan Harga Beras Bulan Januari, 2015

Sumber: Pusat Informasi Harga Bahan Pokok Strategis Di Provinsi Sulawesi Utara Tahun 2015.

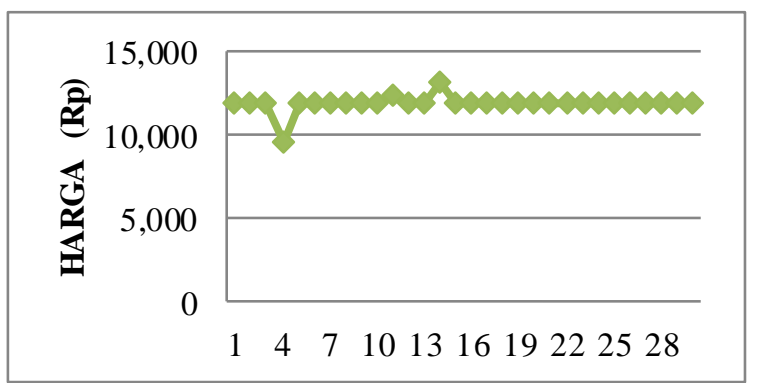

Gambar 4. Perubahan Harga Beras Bulan Februari, 2015

Sumber : Pusat Informasi Harga Bahan Pokok Strategis Di Provinsi Sulawesi Utara Tahun 2015.
Gambar 4 menunjukkan perubahan harga jual beras pedagang pada Bulan Februari. Perubahan harga jual terjadi pada tanggal 3 Rp.11.855/Kg menurun pada tanggal 4 menjadi Rp. $9.484 / \mathrm{Kg}$, harga beras kembali naik Rp. $11.855 / \mathrm{Kg}$ pada tanggal 5. Kenaikan harga beras terjadi kembali tepat pada tanggal 14 Rp.13,210/Kg, dan kembali menurun menjadi Rp.11.960/Kg pada tanggal 15 dan terus berlanjut hingga akhir Bulan Februari.

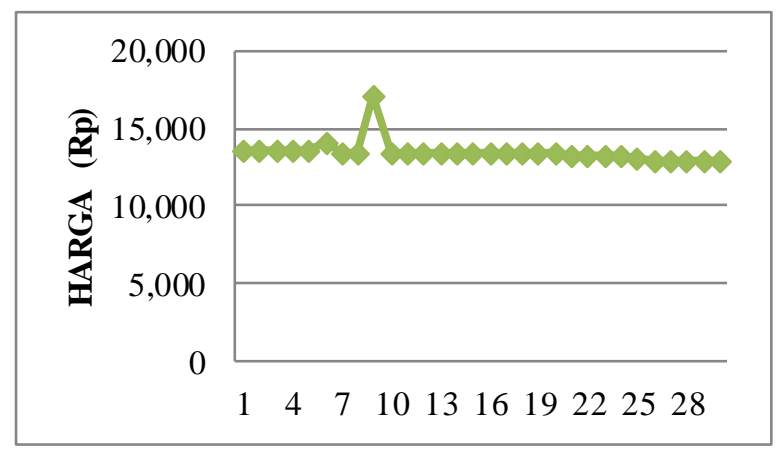

Gambar 5. Perubahan Harga Beras Bulan Maret, 2015

Sumber : Pusat Informasi Harga Bulan Maret, 2015

Gambar 5 menunjukkan perubahan harga jual pedagang yang terjadi pada Bulan Maret. Perubahan harga terjadi minggu awal Bulan Maret dari Rp.11.733/Kg, kenaikan terus terjadi sampai Rp.14.070/Kg pada tanggal 9. Kenaikan harga beras berubah menjadi Rp.16.730/Kg pada tanggal 19, setelah itu menurun kembali menjadi Rp. $13.802 / \mathrm{Kg}$ pada tanggal 20. Harga jual beras dari pedagang terus terjadi perubahan hingga akhir Bulan Maret.

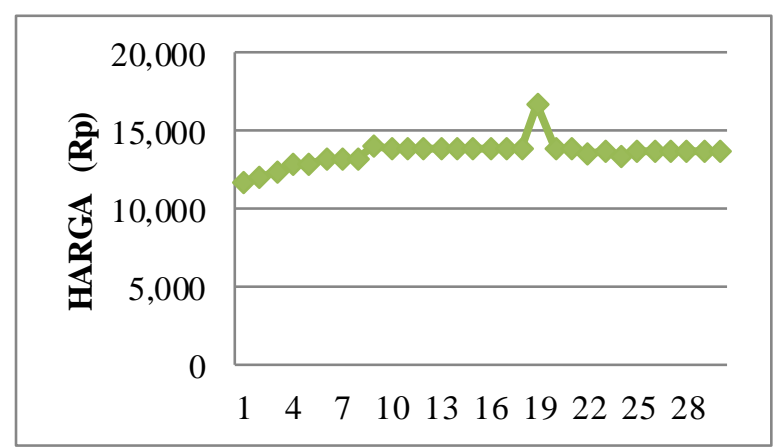

Gambar 6. Perubahan Harga Beras Bulan April, 2015

Sumber : Pusat Informasi Harga Bahan Pokok Strategis Di Provinsi Sulawesi Utara Tahun 2015. 
Gambar 6 menunjukkan adanya perubahan harga jual beras pedagang ke konsumen pada Bulan April. Harga beras terus berubah, pada tanggal 9 harga naik dari Rp.13.385/kg menjadi Rp.17.060/Kg dan kembali menurun Rp.13.385/kg pada tanggal 10, dan harga beras terus berlanjut mengalami penurunan hingga akhir Bulan April.

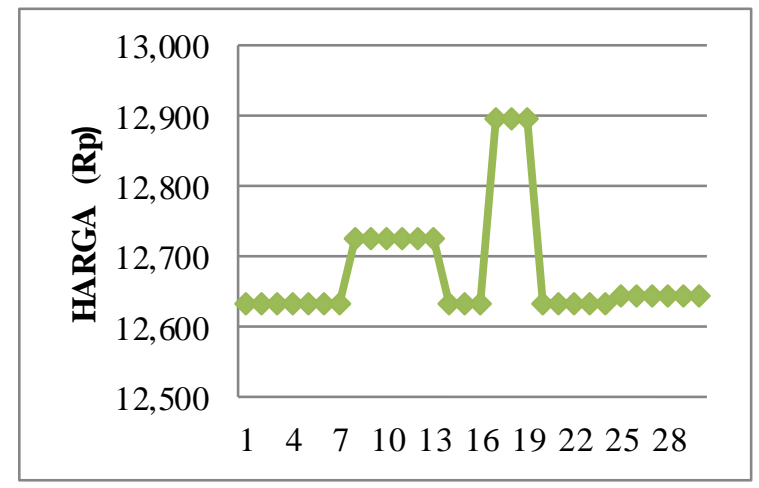

Gambar 7. Perubahan Harga Beras Bulan Mei, 2015

Sumber : Pusat Informasi Harga Bahan Pokok Strategis Di Provinsi Sulawesi Utara Tahun 2015.

Gambar 7 menunjukkan perubahan harga jual beras pedagang ke konsumen pada Bulan Mei. Penurun harga terjadi pada minggu awal Bulan Mei menjadi Rp.13.060/Kg, dan naik kembali pada tanggal 5 menjadi Rp.13.380/Kg, selanjutnya harga terus mengalami penurunan harga sampai Rp.8.370/Kg hingga pada tanggal 19 dan naik kembali pada tanggal 23 menjadi Rp. $12.635 / \mathrm{Kg}$, harga terus berlanjut hingga akhir Bulan Mei.

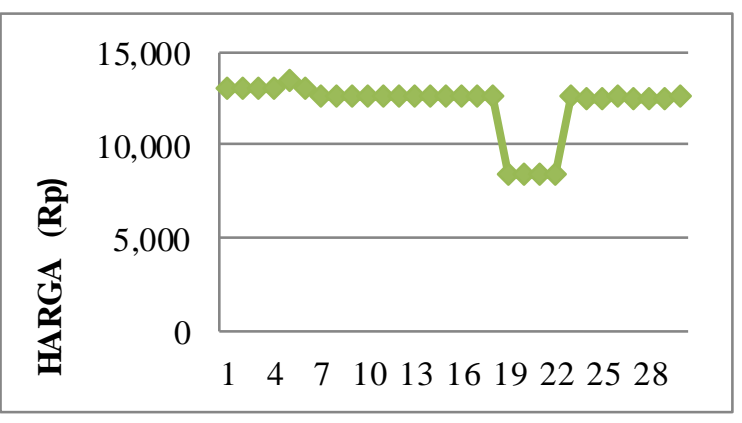

Gambar 8. Perubahan Harga Beras Bulan Juni, 2015

Sumber: Pusat Informasi Harga Bahan Pokok Strategis Di Provinsi Sulawesi Utara Tahun 2015.
Gambar 8 menunjukkan perkembangan harga jual beras pedagang ke konsumen pada Bulan Juni. Harga beras mulai mengalami perubahan pada minggu ke dua Bulan Juni, tanggal 12 harga beras dari Rp. $12.635 / \mathrm{Kg}$ turun menjadi Rp.11.160/Kg, dan kembali naik pada tanggal 13 menjadi Rp. $13.635 / \mathrm{Kg}$. tanggal 15 harga beras kembali menurun menjadi Rp.12.132/Kg. Kenaikan terjadi kembali pada tanggal 20 menjadi Rp. $12.843 / \mathrm{Kg}$, setelah itu harga beras turun kembali menjadi Rp.12.132/Kg, terus berlanjut sampai akhir Bulan Juni.

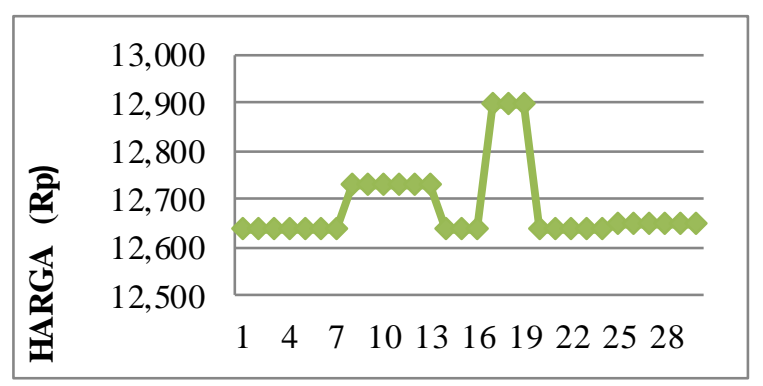

Gambar 9. Perubahan Harga Beras Bulan Juli, 2015

Sumber : Pusat Informasi Harga Bahan Pokok Strategis Di Provinsi Sulawesi Utara Tahun 2015.

Gambar 9 menunjukkan perkembangan harga jual pedagangan ke konsumen pada Bulan Juli. Pada awal minggu Bulan Juli harga jual beras Rp.12.635/Kg dan pada tanggal 7 terjadi kenaikan harga beras menjadi Rp.12.727/Kg. harga beras menurun kembali menjadi Rp.12.635/Kg pada tanggal 14 dan harga kembali mengalami kenaikan pada tanggal 17 menjadi Rp.12.898/Kg. Harga kembali menurun menjadi Rp.12.635/Kg pada tanggal 20 Juli, dan perubahan harga beras terjadi kembali naik Rp. $12.645 / \mathrm{Kg}$ tepat pada tanggal 24 sampai akhir Bulan Juli.

Gambar 10 menunjukkan perkem-bangan harga jual yang diberikan pedagang ke konsumen pada Bulan agustus. Awal minggu tepat pada tanggal 1 agustus harga jual beras pedagang Rp.13.526/Kg dan pada tanggal 3 harga beras turun menjadi Rp.12.645/Kg terus berlanjut sampai akhir Bulan Agustus. 


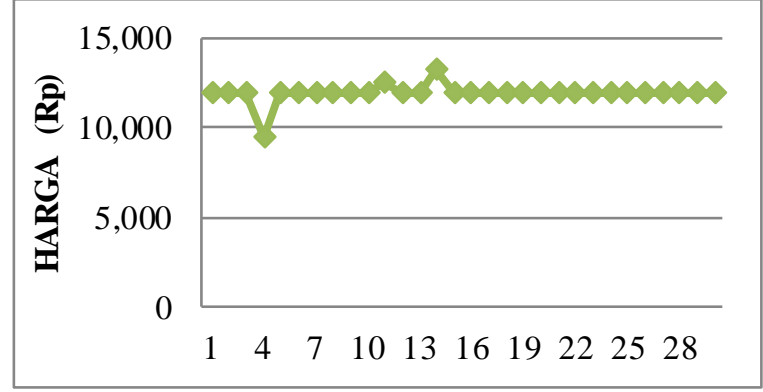

Gambar 10. Perubahan Harga Beras Bulan Agustus, 2015

Sumber : Pusat Informasi Harga Bahan Pokok Strategis Di Provinsi Sulawesi Utara Tahun 2015.

Gambar 11 menunjukkan perkembangan harga jual beras dari pedagang ke konsumen pada Bulan September. Minggu awal dari Bulan September harga beras Rp.12.635/Kg dan pada tanggal 6 harga beras mengalami kenaikan Rp.13.150/Kg, kenaikan harga beras terus berlanjut hingga menjadi Rp.17.120/Kg pada tanggal 16. Harga beras kembali menurun pada tanggal 17 menjadi Rp.13.150/Kg terus berlanjut sampai akhir Bulan September.

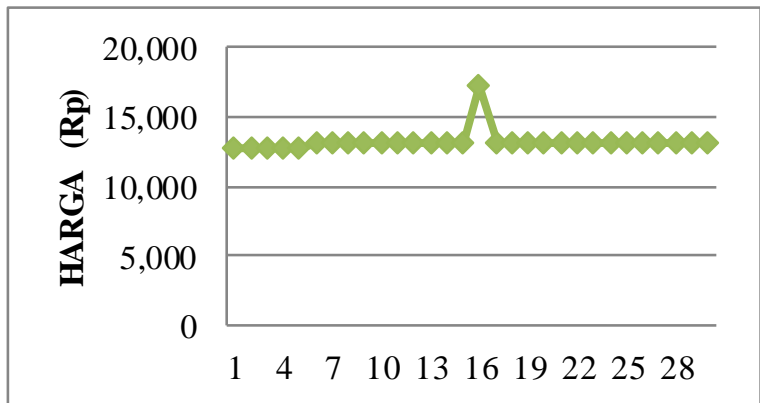

Gambar 11. Perubahan Harga Beras Bulan September, 2015

Sumber : Pusat Informasi Harga Bahan Pokok Strategis Di Provinsi Sulawesi Utara Tahun 2015.

Gambar 12 menunjukkan perkembangan harga jual beras dari pedagang ke konsumen pada Bulan Oktober. Awal minggu pada Bulan Oktober harga jual beras Rp.13.135/Kg. Pada tanggal 8 harga beras mengalami penurunan menjadi Rp.13.115/Kg dan tanggal 21 harga beras mengalami kenaikan menjadi Rp.14.030/Kg dan kembali menurun pada tanggal 22 menjadi Rp.13.135/Kg, harga tersebut terus berlanjut sampai akhir Bulan Oktober.

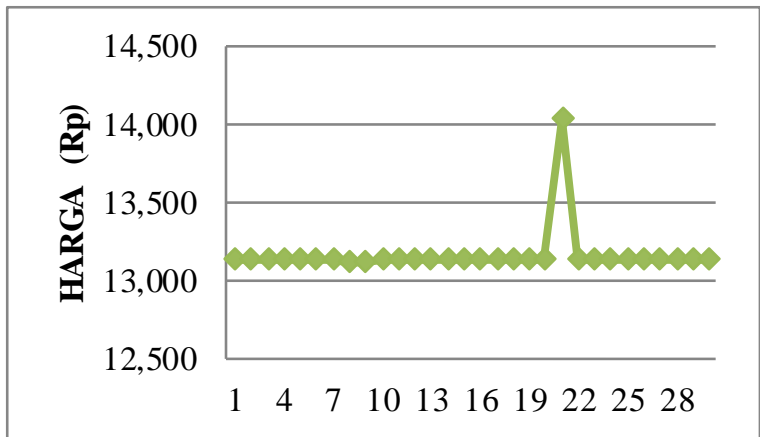

Gambar 12. Perubahan Harga Beras Bulan Oktober, 2015

Sumber : Pusat Informasi Harga Bahan Pokok Strategis Di Provinsi Sulawesi Utara Tahun 2015

Gambar 13 menunjukkan perkembangan harga jual beras dari pedagang ke konsumen pada Bulan November. Awal minggu pada Bulan November harga jual beras Rp.13.135/Kg, memasuki minggu ke dua Bulan November harga beras mengalami kenaikan tepatnya pada tanggal 10 menjadi Rp.13.295/Kg, harga beras ini tetap bertahan sampai pada tanggal 25, setelah itu harga melonjak naik menjadi Rp.14.050/Kg pada tanggal 26, kemudian harga beras kembali menurun seperti harga minggu ke dua Bulan November menjadi Rp.13.295/Kg, harga ini terus berlanjut sampai akhir Bulan.

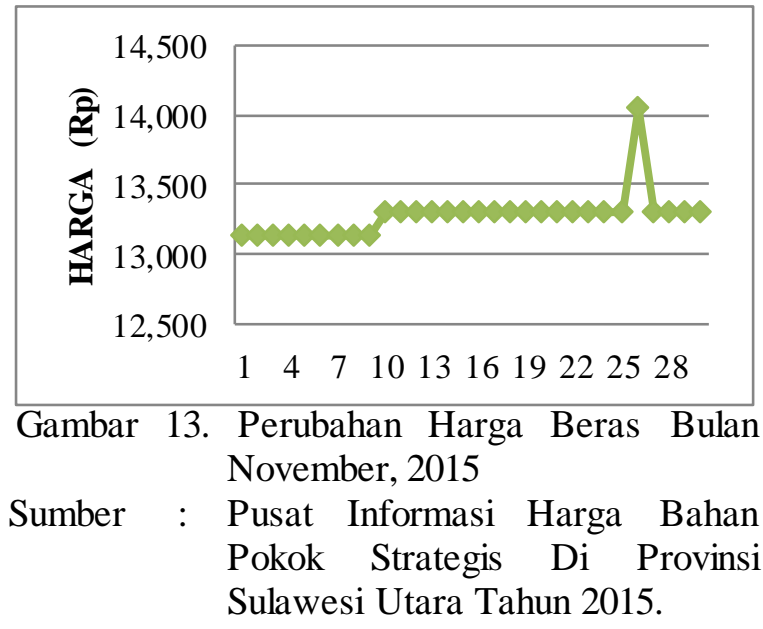




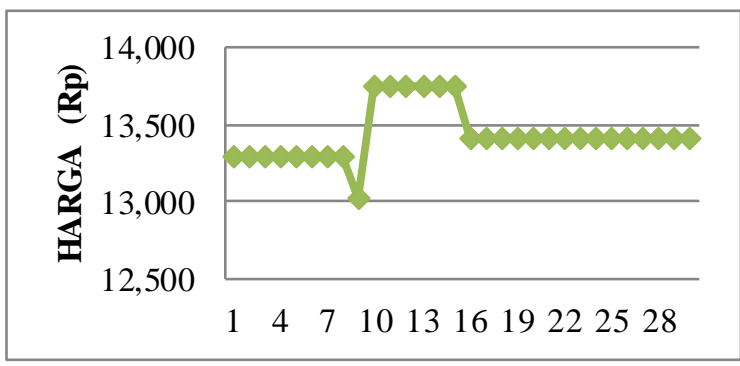

Gambar 14. Perubahan Harga Beras Bulan Desember, 2015

Sumber : Pusat Informasi Harga Bahan Pokok Strategis Di Provinsi Sulawesi Utara Tahun 2015.

Gambar 14 menunjukkan perkembangan harga jual pedagangan ke konsumen pada Bulan Desember tahun 2015. Pada awal minggu Bulan Desember harga jual beras Rp.13.295/Kg, selanjutnya pada tanggal 9 harga beras mengalami penurunan menjadi Rp.13.033/Kg, dan kembali mengalami kenaikan pada tanggal 10 harga beras menjadi Rp.13.755/Kg, kemudian pada tanggal 16 harga beras mengalami penurunan menjadi Rp.13.285/Kg. harga beras terus naik hingga menjadi Rp. 13.410/Kg dari tanggal 27 sampai tanggal 31 Desember.

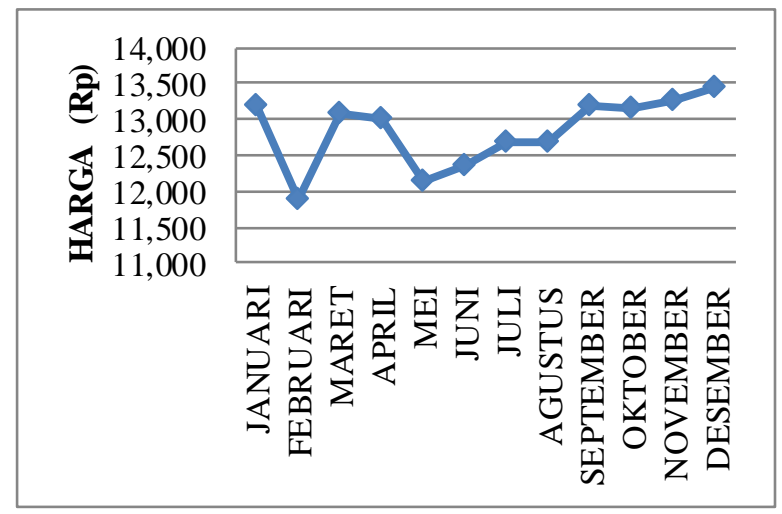

Gambar 15. Perubahan Harga Bahan Pokok Beras, 2015

Sumber : Pusat Informasi Harga Bahan Pokok Strategis Di Provinsi Sulawesi Utara Tahun 2015.

Gambar 15 menjelaskan perkembangan dari pada harga jual beras pedagang ke konsumen di provinsi Sulawesi utara dari Bulan Januari sampai Bulan Desember tahun 2015, harga jual ini juga berlaku untuk semua pedagang beras salah satunya pedagang yang ada di Manado. Pada Bulan Januari harga jual beras pedagang ke konsumen Rp. 13,189/Kg, setelah itu pada Bulan Februari harga beras menurun menjadi Rp. 11,903/Kg, kembali naik pada Bulan maret menjadi Rp. 13,094/Kg. Harga turun kembali pada Bulan april menjadi Rp. $13,016 / \mathrm{Kg}$ terus turun hingga Rp. $12,139 / \mathrm{Kg}$ sampai Bulan mei. Peningkatan harga beras terjadi kembali pada Bulan juni, harga beras menjadi Rp. $12,370 / \mathrm{Kg}$ dan harga beras terus berlanjut naik sampai Bulan Desember menjadi Rp. 13,435/Kg

Ketidakpastian akan penentuan harga inilah yang mengganggu pedagang yang ada di Kota Manado, karena dengan adanya perubahan harga yang terus terjadi mengubah setiap harga jual dari produsen ke konsumen dan mengganggu efisiensi dari stok, stok yang harus di kurangi, di tambah atau stok yang tetap dengan sebelumnya, karena harga mempengaruhi ketersediaan pedagang akan stok, modal, hingga mempengaruhi output dan pendapatan pedagang. Perubahan harga akan mengganggu aktivitas penjualan dari setiap pedagang beras.

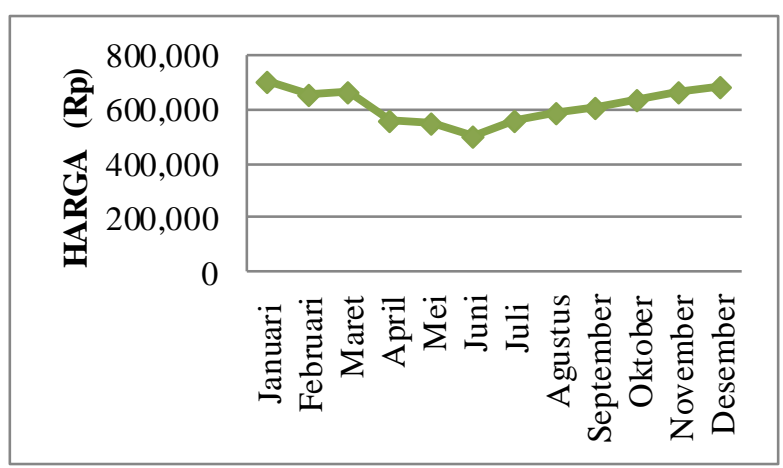

Gambar 16. Perubahan Harga Beli Pedagang Beras Di Kota Manado Tahun 2015

Sumber : Data Olahan, 2015

Gambar 16 menunjukkan perkembangan dari harga beli pedagang beras di Kota Manado dari Bulan Januari sampai Bulan Desember tahun 2015. Perubahan harga beras terus terjadi setiap Bulannya. Bulan Januari harga beras Rp.705.000/karung, dan pada Bulan Februari harga beras menurun menjadi Rp.650.000/karung, harga kembali naik 
menjadi Rp.660.000/karung pada Bulan Maret. Penurunan harga beras terjadi kembali dari Bulan April sampai Bulan Juni, dari Rp.560.000 perkarung menjadi Rp.500.000 perkarung, penyebab harga beras terus turun karena Bulan April sampai Bulan Juni adalah masa panen dari petani, sehingga penawaran akan beras semakin bertambah banyak dan mempengaruhi stok pedagang. Bulan Juli hingga Bulan Desember harga beras terus terjadi peningkatan terus menerus, hal ini terjadi karena stok pedagang yang mulai berkurang, sedangkan permintaan yang meningkat karena dari Bulan Juli sampai Bulan Desember menjelang hari besar atau hari raya yang menyebabkan permintaan konsumen lebih banyak dan semakin bertambah dibandingkan dengan sebe-lumnya, ataupun harihari sebelumnya. Bulan Desember harga beli pedagang beras mengalami kenaikan dari Rp.660.000/karung pada Bulan November menjadi Rp.685.000 perkarung pada Bulan Desember.

\section{Hasil Data dari Pedagang Beras}

\section{Pengaruh Modal Terhadap Pendapatan Pedagang Beras}

Modal merupakan faktor produksi yang digunakan untuk menjalakan suatu usaha, dan digunakan sebagai input produktif dalam produksi selanjutnya. Semakin rendah biaya modal akan makin tinggi keinginan melakukan investasi (Nopirin, 2014).

Tabel 1. Sebaran Pedagang menurut Modal di Pasar Bersehati Manado

\begin{tabular}{lcc}
\hline \multicolumn{1}{r}{ Modal } & Responden & $\%$ \\
\hline Bertambah & 7 & 58 \\
Tetap & 3 & 25 \\
Berkurang & 2 & 17 \\
\hline Jumlah & 12 & 100 \\
\hline
\end{tabular}

Sumber: Data Olahan, 2015

Tabel 1 menjelaskan bahwa pada pasar Bersehati Kelurahan Calaca di Kota Manado sebagian besar modal pedagang beras bertambah dengan jumlah 7 orang pedagang $(58 \%)$, modal tetap 3 orang pedagang $(25 \%)$, dan modal berkurang sebanyak 2 orang pedagang (17\%).

Tabel 2. Sebaran Pedagang menurut Modal di Pasar Pinas ungkulan Karombasan Manado

\begin{tabular}{lcc}
\hline \multicolumn{1}{c}{ Modal } & Responden & $\%$ \\
\hline Bertambah & 19 & 100 \\
Tetap & - & - \\
Berkurang & - & - \\
\hline Jumlah & 19 & 100
\end{tabular}

Sumber : Data Olahan, 2015

\section{Pengaruh Harga Terhadap Pendapatan Pedagang}

Harga adalah sejumlah nilai yang ditukarkan konsumen dengan manfaat dari memiliki atau menggunakan produk barang atau jasa yang nilainya ditetapkan oleh pembeli dan penjual melalui tawar-menawar atau ditetapkan oleh penjual untuk suatu harga yang sama terhadap seorang pembeli (Husein, 2002 dalam Adi,2012).

Tabel 3. Sebaran Pedagang menurut Harga di Pasar Bersehati Manado

\begin{tabular}{lcc}
\hline Harga naik & Responden & $\%$ \\
\hline Selalu & 5 & 42 \\
Tidak & 7 & 58 \\
selalu & & 100 \\
\hline Jumlah & 12 &
\end{tabular}

Sumber: Data Olahan, 2015

Tabel 3 menjelaskan bahwa, pada pasar Bersehati Kelurahan Calaca di Kota Manado menurut pengalaman pedagang beras sebagian besar berpendapat bahwa tidak setiap Bulan harga beras mengalami kenaikan sebanyak 7 orang pedagang (58\%) dan 5 orang pedagang (42\%) berpendapat selalu ada kenaikan untuk harga beras. 
Tabel 4. Sebaran Pedagang menurut Harga di Pasar Pinasungkulan Karombasan Manado

\begin{tabular}{lcc}
\hline Harga naik & Responden & $\%$ \\
\hline Selalu & 1 & 5 \\
Tidak selalu & 18 & 95
\end{tabular}

\begin{tabular}{lll}
\hline Jumlah & 1900
\end{tabular}

Sumber : Data Olahan, 2015

Tabel 4 menjelaskan bahwa, pada pasar Pinasungkulan Karombasan di Kota Manado menurut pengalaman pedagang beras sebagian besar berpendapat bahwa tidak setiap Bulan harga beras mengalami kenaikan sebanyak 18 orang pedagang $(95 \%)$ dan 1 orang pedagang (5\%) berpen-dapat selalu ada kenaikan untuk harga beras.

\section{Pengaruh Stok Terhadap Pedagang Beras} Stok merupakan persediaan yang dilakukan, yang berupa sejumlah barang yang disediakan untuk memenuhi permintaan dari pelanggan atau barang-barang yang disimpan untuk digunakan atau dijual pada masa atau periode yang akan datang.

Tabel 5. Sebaran Pedagang menurut Stok di Pasar Bersehati Manado

\begin{tabular}{lcc}
\hline \multicolumn{1}{c}{ Stok } & Responden & $\%$ \\
\hline Bertambah & - & - \\
Tetap & 5 & 42 \\
Berkurang & 7 & 58 \\
\hline Jumlah & 12 & 100
\end{tabular}

Sumber: Data Olahan, 2015

Tabel 5 menjelaskan bahwa pada pasar Bersehati Kelurahan Calaca di Kota Manado sebagian besar stok dari pedagang beras yang berkurang ketika adanya kenaikan harga beras sebanyak 7 orang pedagang $(58 \%)$ dan stok pedagang yang tetap sebanyak 5 orang pedagang $(42 \%)$.
Tabel 6. Sebaran Pedagang menurut Stok di Pasar Pinasungkulan Karom-basan Manado

\begin{tabular}{|c|c|c|}
\hline Stok & Responden & $\%$ \\
\hline Bertambah & 2 & \\
\hline Tetap & 17 & 89 \\
\hline Berkurang & - & - \\
\hline Jumlah & 19 & $\overline{100}$ \\
\hline
\end{tabular}

Sumber : Data Olahan, 2015

Tabel 6 menjelaskan bahwa pada pasar Pinasungkulan Karombasan di Kota Manado sebagian besar stok dari pedagang beras yang tetap atau tidak berubah ketika adanya kenaikan harga beras sebanyak 17 orang pedagang $(89 \%)$ dan stok pedagang yang bertambah sebanyak 2 orang pedagang $(11 \%)$.

\section{Pengaruh Output Terhadap Pendapatan Pedagang}

Output merupakan hasil yang keluarkan dari suatu proses, atau jumlah beras yang di jual oleh pedagang.

Tabel 7. Sebaran Pedagang menurut Output di Pasar Bersehati Manado

\begin{tabular}{ccc}
\hline Output & Responden & $\%$ \\
\hline Bertambah & 2 & 17 \\
Tetap & 2 & 17 \\
Berkurang & 8 & 66 \\
\hline Jumlah & 12 & 100 \\
\hline
\end{tabular}

Sumber: Data Olahan, 2015

Tabel 7 menjelaskan bahwa pada pasar Bersehati Kelurahan Calaca pedagang beras sebagian besar mengalami berkurangnya output ketika terjadi kenaikan harga beras sebanyak 8 orang pedagang $(66 \%)$ dan pedagang yang mengalami pertambahan output sebanyak 2 orang pedagang (17\%) dan output yang tetap sebanyak 2 orang pedagang beras $(17 \%)$. 
Tabel 8. Sebaran Pedagang menurut Output di Pasar Pinasungkulan Karombasan Manado

\begin{tabular}{lcc}
\hline \multicolumn{1}{c}{ Output } & Responden & $\%$ \\
\hline Bertambah & 2 & 10 \\
Tetap & 11 & 58 \\
Berkurang & 6 & 32 \\
\hline Jumlah & 19 & 100 \\
\hline
\end{tabular}

Tabel 8 menjelaskan bahwa pada pasar Pinasungkulan Karombasan pedagang beras sebagian besar mengalami output yang tetap atau tidak berubah ketika terjadi kenaikan harga beras sebanyak 11 orang pedagang (58\%) dan pedagang yang mengalami berkurangnya output sebanyak 6 orang pedagang $(32 \%)$ dan output bertambah sebanyak 2 orang pedagang beras $(10 \%)$.

Hasil penelitian menjelaskan setiap kali adanya kenaikan harga beras akan mempengaruhi output ke dua pasar tersebut. Kenaikan harga membuat pedagang beras mengalami penurunan atau berkurangnya jumlah yang terjual, ketika adanya kenaikan harga beras pedagang merasa permintaan semakin sedikit atau pembeli berkurang, dan ada juga pedagang beras yang mengalami kesulitan untuk menjual beras perkarungnya dalam sehari. Pedagang yang memiliki output yang tetap atau tidak ada perubahan dalam jumlah yang terjual atau kenaikan harga beras tidak mempengaruhi output dari pedagang, tapi dari penjualan yang tetap ini pedagang mengakui bahwa keuntungan hanya sedikit atau lebih minim tidak seperti biasa, namun pedagang beras harus melakukan hal tersebut agar konsumen tetap mau membeli dagangan pedagang beras. Sebagian kecil dari pedagang yang lain merasakan output yang bertambah ketika adanya kenaikan harga beras karena beras yang di jual adalah beras stok, atau beras yang di beli pedagang saat harga beras belum mengalami kenaikan sehingga pedagang mendapat keuntungan yang berlipat dari sebelumnya, biasanya hal ini dialami oleh pedangang-pedagang pengumpul. Tempat penjualan, perbedaan harga jual beras pedagang ke konsumen, juga mempengaruhi output dari pedagang.

\section{Sebaran Pedagang Menurut Pendapatan Di Pasar Bersehati Pinasungkulan Karom- basan Manado \\ Pendapatan merupakan penghasilan yang di dapat dari suatu usaha dan bisa menjadi pemasukan, atau modal.}

\begin{tabular}{lcc} 
Tabel 9. & $\begin{array}{c}\text { Sebaran Pedagang } \\
\text { Pendapatan di } \\
\text { Bersehati }\end{array}$ Manado & $\begin{array}{c}\text { menurut } \\
\text { Pasar }\end{array}$ \\
\hline Pendapatan & Responden & $\%$ \\
\hline Bertambah & 2 & 17 \\
Tetap & 3 & 25 \\
Berkurang & 7 & 58 \\
\hline Jumlah & 12 & 100
\end{tabular}

Sumber : Data Olahan, 2015

Tabel 9 menjelaskan bahwa pada pasar Bersehati Kelurahan Calaca sebagian besar pendapatan berkurang ketika adanya kenaikan harga yang terjadi sebanyak 7 orang pedagang (58\%), pendapatan yang tetap atau tidak berubah sebanyak 3 orang pedagang (25\%), dan pendapatan yang bertambah sebanyak 2 orang pedagang beras (2\%).

Tabel 10. Sebaran Pedagang menurut Pendapatan di Pasar Pinasungkulan Karombasan Manado

\begin{tabular}{lcc}
\hline \multicolumn{1}{c}{ Pendapatan } & Responden & $\%$ \\
\hline Bertambah & 4 & 21 \\
Tetap & 8 & 42 \\
Berkurang & 7 & 37 \\
\hline Jumlah & 19 & 100 \\
\hline
\end{tabular}

Sumber : Data Olahan, 2015

Tabel 10 menjelaskan bahwa pada pasar Pinasungkulan Karombasan sebagian besar pendapatan yang tetap atau tidak berubah ketika adanya kenaikan harga yang terjadi sebanyak 8 orang pedagang (42\%), pendapatan berkurang sebanyak 7 orang pedagang (37\%), 
dan pendapatan yang bertambah sebanyak 4 orang pedagang beras $(21 \%)$.

\section{Hasil Analisis Model Regeresi}

Hasil olahan data menggunakan SPSS 16 dapat di lihat persamaan yang di peroleh sebagai berikut :

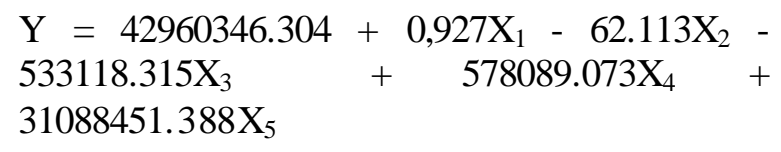

Berdasarkan hasil data analaisis dalam penelitian faktor-faktor yang mempengaruhi pendapatan pedagang beras dalam menghadapi kenaikan harga, dengan variabel independen modal, harga, stok, output, dan dumy $0=$ tidak ada kenaikan, 1 = ada kenaikan. Nilai $\mathrm{R}^{2}$ yang di dapat 1,000 atau $100 \%$, nilai Square yaitu 1,000 atau $100 \%$, dan nilai Adjusted R Square 0,999 atau $99,9 \%$.

a. Nilai konstan (Y) sebesar 42960346.304 yang berarti bahwa jika modal, harga, stok, dan output sama dengan nol maka pendapatan pedagang beras sebesar 42960346.304.

b. Variabel Modal

Koefisien regresi variabel modal dari perhitungan linear berganda didapat nilai koefisien $\left(b_{1}\right)$ sebesar 0,927 , yang menyatakan setiap penambahan modal sebesar satu juta rupiah, maka akan terjadi peningkatan pendapatan (Y) pedagang beras sebesar 0,92 rupiah, hal ini menunjukkan modal memiliki pengaruh terhadap peningkatan pendapatan pedagang beras.

c. Variabel harga

Koefisien regresi variabel harga dari perhitungan linear berganda didapat nilai koefisien $\left(b_{2}\right)$ sebesar -62.113, yang menyatakan bahwa setiap terjadi penambahan harga seratus ribu rupiah maka akan terjadi penurunan pendapatan pedagang beras sebesar -62.113 rupiah.

c. Variabel stok

Koefisien regresi variabel stok dari perhitungan linear berganda didapat nilai koefisien $\left(b_{3}\right)$ sebesar -533118.315 , yang menyatakan bahwa setiap terjadi penambahan stok satu karung maka akan terjadi penurunan pendapatan pedagang beras sebesar 533118.315, rupiah, hal ini terjadi karena setiap adanya penambahan stok akan mengurangi pendapatan, atau mengeluarkan uang yang dimiliki untuk membeli tambahan stok beras pedagang.

d. Variabel output

Koefisien regresi variabel output dari perhitungan linear berganda didapat nilai koefisien $\left(b_{4}\right)$ sebesar 578089.073, yang menyatakan bahwa setiap terjadi penambahan output satu karung maka akan terjadi penambahan terhadap pendapatan pedagang beras sebesar 578089.073 rupiah, output merupakan jumlah yang dijual pedagang, sehingga menghasilkan pendapatan untuk pedagang beras.

e. Variabel dumy

Koefisien regresi variabel dumy dari perhitungan linear berganda didapat nilai koefisien $\left(b_{4}\right)$ sebesar 31088451.388, yang menyatakan bahwa setiap adanya kenaikan sebesar satu rupiah maka akan mengakibatkan kenaikan pendapatan pedagang beras 31088451.388 rupiah, begitu juga ketika tidak ada kenaikan sebesar satu rupiah akan mengakibatkan kenaikan pendapatan pedagang beras sebesar 31088451.388 .

\section{a. Pengaruh Modal Terhadap Pendapatan Pedagang Beras}

Modal memberikan pengaruh pada pendapatan pedagang beras di pasar bersehati dan pasar pinasungkulan manado dalam menghadapi kenaikan harga. Variabel modal usaha berpengaruh positif terhadap pendapatan pedagang beras di pasar bersehati dan pasar pinasungkulan manado, Peningkatan modal usaha dapat meningkatkan pendapatan pedagang beras. Modal paling rendah sebesar Rp. 11,500,000.00 dan modal paling tinggi sebesar Rp. 5,193,000,000.00 dengan rata-rata dari modal sebesar Rp. 389,011,935,- dan ratarata pendapatan sebesar Rp. 278,334,354,- per Bulan.

Hasil penelitian menjelaskan pedagang beras kedua pasar dari pasar Bersehati sampai pasar Pinasungkulan Karombasan dalam menghadapi kenaikan harga, sebagian besar pedagang beras mengalami pertambahan modal ketika kenaikan harga mulai terjadi di 
pasar-pasar tersebut. Sebagian kecil dari kedua pasar tersebut ada juga pedagang yang mengurangi atau tetap dengan modal awal ketika kenaikan harga terjadi, tetapi akan mempengaruhi stok pedagang beras, jumlah beras tidak akan sama lagi dengan sebelumnya ketika harga beras mulai mengalami kenaikan secara menyeluruh. Sebagian pedagang kekurangan modal untuk membeli beras kembali.

\section{b. Pengaruh Harga Terhadap Pendapatan Pedagang Beras}

Variabel harga berpengaruh negatif terhadap pendapatan pedagang beras di pasar bersehati dan pasar pinasungkulan manado dalam menghadapi kenaikan harga. Berdasarkan hukum permintaan semakin tinggi harga suatu barang maka semakin menurunnya permintaan konsumen, sebalik-nya jika semakin rendah harga barang maka semakin tinggi permintaan konsumen. permintaan konsumen berkurang karena harga terus mengalami peningkatan akibatnya mempengaruhi pendapatan pedagang beras.

Hasil analisis yang didapat dari penelitian ini, didapat Nilai probabilitas lebih besar dari $0,05(0,293>0,05)$ dan nilai t tidak signifikan, membuat $\mathrm{H}_{1}$ ditolak dan $\mathrm{H}_{0}$ diterima, yang berarti harga tidak bepengaruh terhadap pendapatan pedagang beras di pasar bersehati dan pasar pinasungkulan manado dalam menghadapi kenaikan harga. Hasil penelitian menjelaskan pedagang beras dari kedua pasar dari pasar Bersehati kelurahan Calaca sampai pasar Pinasungkulan Karombasan berpendapat tidak setiap Bulan mengalami kenaikan harga beras. Kenaikan harga beras terjadi selalu tidak menentu dan sering harga beras naik ketika stok beras mulai berkurang, karena kemarau panjang sehingga menghasilkan jumlah beras lebih sedikit atau terjadi gagal panen yang berakibat harga melonjak naik. Pedagang mengungkapkan kenaikan harga sering terjadi perBulan dan perminggu atau perharinya juga dan ketika harga naik kemungkinan besar harga beras akan terus naik tidak akan pernah menurun kembali. Kenaikan harga ini membuat pedagang harus menetapkan strategi, seperti pedagang yang menahan stok, karena pedagang mengetahui harga beras akan terus naik apalagi belum musim panen, dan dikarenakan cuaca. Ketika harga mulai naik pedagang mulai mengeluarkan stok beras yang dimilikinya, alasan pedagang menahan stok beras karena pada saat harga beras turun maka permintaan akan semakin meningkat atau semakin banyak.

\section{c. Pengaruh Stok Terhadap Pendapatan Pedagang Beras}

Variabel stok berpengaruh negatif terhadap pendapatan pedagang beras di pasar bersehati dan pasar pinasungkulan manado dalam menghadapi kenaikan harga, hal ini terjadi karena setiap adanya penambahan stok akan mengurangi pendapatan, atau mengeluarkan uang yang dimiliki untuk membeli tambahan stok beras pedagang. Hasil analisis dari regresi ditunjukan nilai probabilitas lebih kecil dari $0,05(0,000<0,05)$, menunjukkan nilai $\mathrm{t}$ yang di peroleh tersebut signifikan, sehingga $\mathrm{H}_{0}$ di tolak dan $\mathrm{H}_{1}$ diterima, yang berarti stok berpengaruh nyata terhadap pendapatan pedagang beras di pasar bersehati dan pasar pinasungkulan manado dalam menghadapi kenaikan harga.

Hasil penelitian menjelaskan setiap kali adanya kenaikan harga beras akan mempengaruhi stok kedua pasar tersebut. Kenaikan harga membuat pedagang beras mengalami stok berkurang. Pedagang memutuskan untuk mengurangi stok beras karena akibat kenaikan dagangan sepi atau banyak konsumen yang membeli beras hanya sekedar saja, tidak dapat membeli lebih dari yang biasanya.

Pedagang beras mengalami stok tetap atau tidak berubah, biasanya ini terjadi hanya antara pedagang besar dan pedagang pengumpul bahkan pedagang pengecer. Pedagang memutuskan stok beras yang tidak berubah atau tetap karena ini sudah menjadi persyaratan yang di miliki oleh para pedagang. Pedagang terus melakukan pesyaratan bisnis ini karena jika tidak perjanjian di batalkan atau antara pedagang akan memutuskan hubungan mitra bisnis dan tidak ada lagi kepercayaan antara pedagang, pedagang juga tidak takut untuk mengambil keputusan ini karena beras merupakan kebutuhan pokok dari konsumen, sehingga konsumen tidak akan pernah 
menghentikan permintaan akan beras walaupun kenaikan harga beras selalu terjadi. Sebagian pedagang mengalami pertambahan stok beras yaitu pedagang yang memiliki kelancaran dalam berbisnis atau berdagang karena walaupun harga terus naik tapi stok beras pedagang juga terus bertambah karena diikuti dengan permintaan yang lebih banyak lagi, hampir setiap hari pedagang mengeluh karena kehabisan stok beras.

\section{d. Pengaruh Output Terhadap Pendapatan Pedagang Beras}

Variabel output berpengaruh positif terhadap pendapatan pedagang beras di pasar bersehati dan pasar Pinasungkulan Manado dalam menghadapi kenaikan harga. Output yang di maksud dalam penelitian ini adalah jumlah yang terjual, atau jumlah yang di jual pedagang beras setiap Bulannya. Hasil yang didapat dari analisis regresi nilai probabilitas lebih kecil dari $0,05 \quad(0,000<0,05)$, yang menunjukkan nilai $\mathrm{t}$ yang di peroleh tersebut signifikan sehingga $\mathrm{H}_{0}$ di tolak dan $\mathrm{H}_{1}$ diterima, yang berarti stok berpengaruh nyata terhadap pendapatan pedagang beras di pasar bersehati dan pasar pinasungkulan manado dalam menghadapi kenaikan harga.

Hasil penelitian menjelaskan pedagang setiap kali kenaikan harga beras terjadi akan mempengaruhi output ke dua pasar tersebut. Kenaikan harga membuat pedagang beras mengalami penurunan atau berkurangnya jumlah yang terjual, ketika adanya kenaikan harga beras pedagang merasa permintaan semakin sedikit atau pembeli berkurang, dan ada juga pedagang beras yang mengalami kesulitan untuk menjual beras perkarungnya dalam sehari. Pedagang yang memiliki output yang tetap atau tidak ada perubahan dalam jumlah yang terjual atau kenaikan harga beras tidak mempengaruhi output dari pedagang, tapi dari penjualan yang tetap ini pedagang mengakui bahwa keuntungan hanya sedikit atau lebih minim tidak seperti biasa, namun pedagang beras harus melakukan hal tersebut agar konsumen tetap mau membeli dagangan pedagang beras. Sebagian kecil dari pedagang yang lain merasakan output yang bertambah ketika adanya kenaikan harga beras karena beras yang di jual adalah beras stok, atau beras yang di beli pedagang saat harga beras belum mengalami kenaikan sehingga pedagang mendapat keuntungan yang berlipat dari sebelum. Tempat penjualan, perbedaan harga jual beras pedagang ke konsumen, juga mempengaruhi output dari pedagang.

Pedagang setiap kali adanya kenaikan harga beras pedagang mengalami pendapatan yang berbeda-beda, sebagian besar pedagang mengalami pendapatan yang menurun dan pendapatan yang tetap atau tidak berubah, dan sebagian kecil pedagang beras mengalami pertambahan akan pendapatan, itu semua di sesuaikan dengan penjualan perhari, perminggu, per bulannya. Kenaikan harga dapat mengubah pendapatan, perubahan yang menguntungkan atau perubahan yang merugikan, semua disesuaikan dengan output yang berbeda akan memberikan pendapatan yang berbeda juga, jika output hanya sedikit maka akan memberikan hasil atau pendapatan yang sedikit. Strategi pedagang beras dalam mengahadapi kenaikan harga harus dengan membeli stok yang banyak ketika harga turun dan menjual kembali ketika harga mulai naik, sehingga menghasilkan profit.

\section{KESIMPULAN DAN SARAN}

\section{Kesimpulan}

Penelitian ini melihat faktor-faktor yang mempengaruhi pendapatan pedagang beras di pasar Bersehati Calaca dan Pasar Pinasungkulan Karombasan di Kota Manado dalam menghadapi fluktuasi harga. Hasil penelitian dapat disimpulkan sebagai berikut :

Modal, stok, output berpengaruh terhadap pendapatan pedagang beras yang ada di Pasar Bersehati Calaca dan Pasar Pinasungkulan Karombasan di Kota Manado dalam menghadapi fluktuasi harga, sedangkan harga tidak berpengaruh terhadap pendapatan pedagang beras yang ada di Pasar Bersehati Calaca dan Pasar Pinasungkulan Karombasan di Kota Manado dalam menghadapi fluktuasi harga. Fluktuasi harga tidak berpengaruh terhadap pendapatan dari pedagang beras yang ada di Pasar Bersehati Calaca dan Pasar Pinasungkulan Karombasan di Kota Manado. 


\section{Saran}

Berdasarkan hasil penelitian ini menunjukkan peran penting bagi pemerintah untuk pengembangan usaha dengan memberikan bantuan dana untuk penyediaan modal usaha, dan pengontrolan saluran distribusi.

Bagi peneliti selanjutnya diharapkan untuk memasukan faktor-faktor lain yang dapat mempengaruhi pendapatan pedagang, dan skripsi ini bisa digunakan menjadi salah satu refrensi untuk penelitian selanjutnya.

\section{DAFTAR PUSTAKA}

Artaman, D. M. Aris., 2015. Analisis FaktorFaktor Yang Mempengaruhi Pendapatan Pedagang Seni Sukawati Di Kabupaten Gianyar. Tesis. Program Studi Ilmu Ekonomi Universitas Udayana. Denpasar.

Adi F, Albertus., 2012. Analisis Pengaruh Harga, Kualitas Produk, Dan Kualitas Layanan Terhadap Kepuasan Pelanggan. Skripsi. Fakultas Ekonomika dan Bisnis Universitas Diponegoro, Semarang.

Anindita R. dan Reed M. 2008. Bisnis Dan Perdagangan Internasional. Penerbit CV. Andi Offset. Yogyakarta

Adriyansya R. Yanuar., 2014. Analisis Pengaruh Persepsi Harga, Kemenarikan Desain Produk Dan Kualitas Produk Terhadap Kemantapan Keputusan Pembelian (Studi Pada Pembeli Produk Distro House Of Smint Semarang). Skripsi. Fakultas Ekonomika Dan Bisnis Universitas Dipenegoro. Semarang.

Anonimous.,2014. Data Komoditas yang mengalami Kenaikan Harga. Badan Pusat Statistik, Manado.

Amrini Y. Hasdi A. Efrizal S., 2012. Analisis Kebijakan Moneter Terhadap Inflasi Dan Perekonomian Di Indonesia. Skripsi. (Akses tanggal 19 Mei 2015).
Aslamiyah S, Lely., 2008. Pengaruh Saluran Distribusi dan Harga Terhadap Volume Penjualan Pada Industri Rumah Tangga Sodok di Desa Karangrejo Kecamatan Purwasari Kabupaten Pasuruan. Skripsi. Program Studi Pendidikan Ekonomi Jurusan Pendidikan IPS Fakultas Tarbiyah Universitas Islam Negeri Malang, Malang.

Dinas Perindustrian Dan Perdagangan.,2015. Kenaikan Harga Sembako Di Kota Manado.

Feriyanto, Nur.,2014. Ekonomi Sumber Daya Manusia Dalam Perspektif Indonesia Cetakan Pertama. Penerbit UPP STIM YKPN, Yogyakarta.

Hanafie R., 2010. Pengantar Ekonomi Pertanian. Penerbit C.V. Andi offset, Yogyakarta.

Hessie, R.,2009. Analisis Produksi Dan Konsumsi Beras Dalam Negeri Serta Implikasinya Terhadap Swasembada Beras di Indonesia. Skripsi. Departemen Ekonomi Sumberdaya dan Lingkungan Fakultas Ekonomi Dan Manajemen Institut Pertanian Bogor, Bogor.

Leksono A., 2013. Faktor-Faktor Yang Mempengaruhi Pendapatan Industri Kreatif di Indonesia Tahun 20022008. Skripsi. Fakultas Ekonomika Dan Bisnis Universitas Dipenogoro. Semarang.

Ma'arif S., 2013. Analisis Faktor-Faktor Yang Mempengaruhi Pendapatan Pedagang Pasar Bandarjo Ungaran Kabupaten Semarang. Skripsi. Jurusan Ekonomi Pembangunan Fakultas Ekonomi Universitas Negeri. Semarang

Mulyo H., 2011. Analisis Permintaan Beras Di Kabupaten Klanten. Skripsi. Fakultas Pertanian Universitas Sebelas Maret, Surakarta.

Nuraeni., 2002. Pengantar Ekonomi Mikro Edisi Pertama, Penerbit Universitas Muhammadiyah, Malang. 
Nuraeni, dan Nasruddin Wasrop., 2014. Manajemen Agribisnis Edisi Kesatu, Penerbit Universitas Terbuka, Tanggerang Selatan.

Nopirin, 2014. Ekonomi Moneter Edisi Pertama. Penerbit BPFE, Yogyakarta.

Pertiwi P., 2015. Analisis Faktor-Faktor Yang Mempengaruhi Pendapatan Tenaga Kerja di Daerah Istimewa Yogyakarta. Skripsi. Program Studi Pendidikan Ekonomi Fakultas Ekonomi Universitas Negeri. Yogyakarta.

Pratama A. Septian., 2013. Analisis FaktorFaktor Yang Mempengaruhi Pendapatan Pedagang Setelah Relokasi di Pasar Purwoyoso Kecamatan Ngaliyan Semarang. Skripsi. Jurusan Ekonomi Pemba-ngunan Fakultas Ekonomi Universitas Negeri. Semarang.

Ritonga A. Syahputra., 2009. Pengaruh modal, potensi keuntungan dan faktor emosional terhadap keputusan menjadi keuntungan (studi pedagang buah di pasar buah berastagi). Skripsi. Fakultas Ekonomi Universitas Sumatera Utara. Medan.

Samosir B. S., 2011. Menentukan Model Koefisien Regresi Multiple Variabel dengan menggunakan maksimum Likelihood. Skripsi. Departement Matematika Fakultas Matematika dan Ilmu Pengetahuan Alam Universitas Sumatera Utara. Medan.

Sulpa, Nadilah., 2014. Proses Penentuan Harga Jual Pada Rumah Makan Citra Minang di Makassar. Skripsi. Jurusan Akuntansi Fakultas Ekonomi Dan Bisnis Universitas Hasanuddin, Makassar.
Sunyoto D. 2015. Strategi Pemasaran Cetakan Pertama. Penerbit Center For Academic Publishing Service. Yogyakarta.

Surono., 2010. Analisis Pengaruh Penetapan Harga, Lokasi, Dan Promosi Terhadap Keputusan Pembelian. Skripsi. Jurusan Manajemen Fakultas Ekonomi Dan Bisnis Universitas Islam Negeri Syarif Hidayatullah, Jakarta.

Soeharno., 2009.Teori Mikro Ekonomi. Penerbit C.V Andi Offset, Yogyakarta.

Setyopurwanto D., 2013. Pengaruh Investasi Sumber Daya Manusia Dan Investasi Modal Terhadap Pendapatan Perkapita Masyarakat Indonesia. Skripsi. Jurusan Ilmu Ekonomi Fakultas Ekonomi Dan Bisnis Universitas Brawijaya, Malang. (Akses tanggal 26 mei 2015).

Tjiptono F. Dan Chandra G. 2012. Pemasaran Strategik Edisi Kedua. Penerbit CV. Andi Offset. Yogyakarta.

Utama B, Rikip., 2011. Pengaruh Saluran Distribusi Terhadap Tujuan Penjualan Produk C.V. Amanda Cabang Antapani Bandung. Skripsi. Fakultas Ilmu Sosial Dan Politik Universitas Pasundan, Bandung.

Yanuta P. A. Tri., 2013. Analisis Pendapatan Petani Tebu Di Kecamatan Jepon Kabupaten Blora. Skripsi. Jurusan Ekonomi Pembangunan Fakultas Ekonomi Universitas Negeri. Semarang. 